\title{
Evaluation of Green Building Cost Based on Life Cycle Theory
}

\author{
Yanli Guo ${ }^{1, a}$, Chengli Zhu², b \\ ${ }^{1}$ School of Yibin Vocational and Technical college, Yibin, Sichuan, 644000, China; \\ ${ }^{2}$ Yibin Railway Construction Co., Ltd, Yibin, Sichuan, 644000, China. \\ a383009062@qq.com, b174344427@qq.com
}

Keywords: Green Building; Cost Evaluation; Influencing Factors; Life Cycle Theory.

\begin{abstract}
With the deteriorating climate and the ever-tightening of available resources, green, environmental and low-carbon buildings are more and more emphasized. On the basis of expounding the connotation and characteristics of green building, this paper uses the life cycle theory to analyze the influencing factors of green building cost. Then, this paper take a green residential district as an example to do the cost evaluation and results analysis, so as to provide idea for the life cycle cost management of green building.
\end{abstract}

\section{Introduction}

With the sustainable development of society, the deteriorating climate and the limited availability resources, as a high energy consumption industry, the construction industry is particularly threatened. Therefore, the architectural concept of environmental protection is more and more emphasized. China Ministry of Housing and Construction will also make the green building development work listed in the "thirteen five" plan, this plan proposed that the urban green building will accounted to $50 \%$ of new construction, and the green building materials will ratio reaches to approximate $40 \%$. To further promote the large scale development process of the green building. However, the construction cost is the key issues.

\section{The Connotation and Characteristics of Green Building}

\subsection{The Connotation of Green Building}

Green building which can save resources, protect environment, reduce pollution, and provide healthy, applicable and efficient use of space for people during the life cycle. Green building is in harmony with nature. The "green" of the "green building" does not refer to the general meaning of the three-dimensional greening, the roof green building garden, but on behalf of a concept or symbol. Green building refers to the building which is built in the environment of environmental basic ecological balance. It harmless to the environment. It can make full use of environmental natural resources. It also can be called sustainable developed architecture.

\subsection{The Characteristics of Green Building}

Compared with the traditional building, green building has the following characteristics:

(1) Conservation

Green building aims to save energy, land, water, materials. The effective use of wind energy, solar energy, bio-energy and marine energy and other renewable energy can achieve the overall energy-saving buildings. Through the restoration of abandoned land to achieve the efficient use of land. By optimizing the indoor and outdoor drainage system, install water purification and recycling equipment to save the total water consumption.

(2) Environmental protection

Green building aims to use green, low-carbon materials, to create a natural harmony between indoor and outdoor environment. Due to green building materials requirements, materials as much as possible to use local resources. Thereby reducing the material transport process, and reducing the resource consumption and the environment pollution. 
(3) Sustainability

Green building theory is built under the guidance of sustainable development ideas. To achieve sustainable development must build green building. It is part of sustainable strategic thinking. The essence of green building is sustainable, and its goal is to realize the sustainable development of the Real Estate Industry.

(4) Human nature

Green building emphasizes the living environment. It focuses on indoor and outdoor environmental quality. And it aims to improve the living comfort and people's happiness index. The ultimate goal of green building is to achieve the harmony of people, nature and architecture.

\section{Life Cycle Cost Theory Analysis}

In the construction field, the full life cycle cost refers to the sum of the costs of all phases which include the building design, development, construction, use until maintenance and retirement. The research core of the life cycle cost is the whole process of construction projects as a research object, and adopt a reasonable cost control strategy to minimize the cost. The core idea of this approach is:

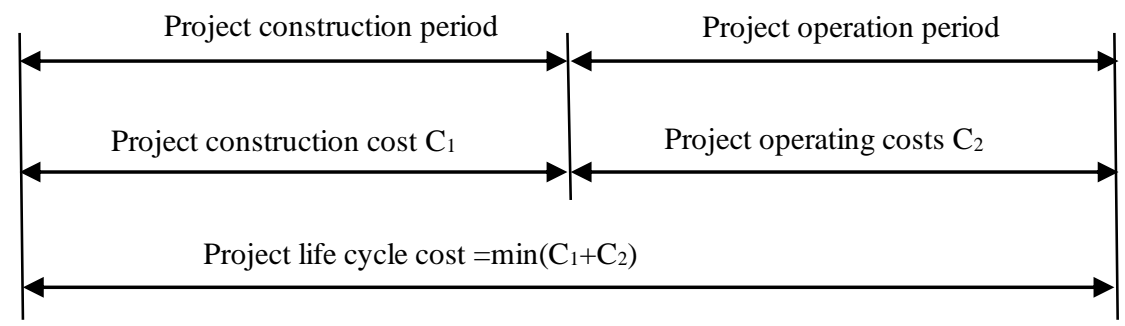

Fig. 1 Schematic diagram of the minimum life cycle cost

As for green building, the life cycle cost includes:

Table 1. The cost composition of green building life cycle

\begin{tabular}{|c|c|c|}
\hline \multirow{14}{*}{$\begin{array}{l}\text { The cost composition of green building } \\
\text { life cycle }\end{array}$} & \multirow{2}{*}{$\begin{array}{c}\text { Decision and project establishment } \\
\text { stage }\end{array}$} & Research costs \\
\hline & & $\begin{array}{l}\text { Feasibility study preparation } \\
\text { costs }\end{array}$ \\
\hline & \multirow{2}{*}{ Design and planning stages } & Land acquisition costs \\
\hline & & Survey and design costs \\
\hline & \multirow{3}{*}{ Construction stage } & Construction costs \\
\hline & & Installation cost \\
\hline & & Other management costs \\
\hline & \multirow{4}{*}{ Maintenance stage } & Equipment depreciation costs \\
\hline & & Transformation cost \\
\hline & & Cleaning costs \\
\hline & & Other related costs \\
\hline & \multirow{3}{*}{ Recovery stage } & Removal costs \\
\hline & & Site cleaning costs \\
\hline & & Recycling value \\
\hline
\end{tabular}

\section{The Influencing Factors of Green Building Life Cycle Cost}

In order to evaluate the life cycle cost of green buildings, it is necessary to select the indicators that have an important impact on the life cycle cost, and start with the indicators to analyze the cost situation. In order to make the evaluation system objectively and truthfully, according to the principle of scientific principle and operability principle, the cost in Table 1 is classified according to the purpose, and the evaluation index system of influencing factors is constructed from four aspects: resource index, technical index, personnel index and environmental index (See table 2): 
Table 2. The evaluation index system of green building life cycle cost

\begin{tabular}{|c|c|c|}
\hline \multirow{15}{*}{$\begin{array}{l}\text { The evaluation index system of green } \\
\text { building life cycle cost (A) }\end{array}$} & $\begin{array}{l}\text { The first grade indexes of } \\
\text { influencing factors }\end{array}$ & $\begin{array}{l}\text { The second grade indexes of } \\
\text { influencing factors }\end{array}$ \\
\hline & \multirow{4}{*}{ Resource indexes (A1) } & $\begin{array}{l}\text { Service condition of green } \\
\text { facilities (A11) }\end{array}$ \\
\hline & & $\begin{array}{l}\text { Local use of green resources } \\
\text { (A12) }\end{array}$ \\
\hline & & Use of green materials (A13) \\
\hline & & $\begin{array}{l}\text { Green material market price } \\
(\mathrm{A} 14)\end{array}$ \\
\hline & \multirow{3}{*}{ Technical indexes (A2) } & $\begin{array}{l}\text { Operations management } \\
\text { technology (A21) }\end{array}$ \\
\hline & & Green technology usage (A22) \\
\hline & & $\begin{array}{l}\text { New technology applicability } \\
\text { (A23) }\end{array}$ \\
\hline & \multirow{3}{*}{ Personnel indexes (A3) } & Personnel employed (A31) \\
\hline & & Technical staff training (A32) \\
\hline & & $\begin{array}{l}\text { Management personnel } \\
\text { participation (A33) }\end{array}$ \\
\hline & \multirow{4}{*}{ Environmental indexes (A4) } & Gas pollution treatment (A41) \\
\hline & & Noise pollution control (A42) \\
\hline & & Solid pollution treatment (A43) \\
\hline & & Sewage treatment (A44) \\
\hline
\end{tabular}

\section{Cost Evaluation of Green Building Life Cycle (Take a Project in Yibin City as an Example)}

\subsection{Project Overview}

Shangye residential district is located in Yibin City. It was developed by Zhengyang Real Estate Development Company. The district to the environment as the main starting point, and it focused on the overall harmonious relationship of the residential area. Combined with the city's geographical location, developer to build a new green residential district, to meet the needs of modern life development.

\subsection{Cost Evaluation Model}

(1)Sorting of factors at all levels

According to the first grade indexes, it construct the judgment matrix use the 1-9 scale method, and compare the relative importance between elements. By obtaining the matrix eigenvector and the eigenvalue, and performing the consistency test, we obtain the weight of the primary index as shown in Table 3.

Table 3. The first grade indexes judgment matrix

\begin{tabular}{|c|c|c|c|c|c|}
\hline $\begin{array}{l}\text { The first grade } \\
\text { indexes }\end{array}$ & $\begin{array}{l}\text { Resource } \\
\text { indexes }\end{array}$ & $\begin{array}{c}\text { Technical } \\
\text { indexes }\end{array}$ & $\begin{array}{c}\text { Personnel } \\
\text { indexes }\end{array}$ & $\begin{array}{l}\text { Environmental } \\
\text { indexes }\end{array}$ & Test \\
\hline Resource indexes & 1 & 1 & 3 & 5 & \multirow{5}{*}{$\begin{array}{c}\lambda_{\max }=4.0043 \\
\mathrm{CI}=0.0014 \\
\mathrm{CR}=0.0016 \\
\mathrm{CR}<0.1\end{array}$} \\
\hline Technical indexes & 1 & 1 & 3 & 5 & \\
\hline Personnel indexes & $1 / 3$ & $1 / 3$ & 1 & 2 & \\
\hline $\begin{array}{l}\text { Environmental } \\
\text { indexes }\end{array}$ & $1 / 5$ & $1 / 5$ & $1 / 2$ & 1 & \\
\hline Index weight $(\mathrm{W})$ & 0.3935 & 0.3935 & 0.1376 & 0.0754 & \\
\hline
\end{tabular}

For each first grade index, using the same method, we can get the weight of each second index.

(2)The weigh summary table of influencing factors as shown in Table 4.

(3)Project score

Ten staff members which are composed of project managers, construction workers and project financiers were invited to rate the each index of the project. The maximum score and the minimum score of each index are removed, and then take the average, we can get the final score of the project cost as shown in Table 4. 
Table 4. The weigh and score of each index

\begin{tabular}{|c|c|c|c|c|c|}
\hline The first grade indexes & Weight & The second grade indexes & Weight & Final weight & Score \\
\hline \multirow{4}{*}{ Resource indexes (A1) } & \multirow{4}{*}{0.3935} & $\begin{array}{l}\text { Service condition of green facilities } \\
\text { (A11) }\end{array}$ & 0.2092 & 0.0823 & 92 \\
\hline & & Local use of green resources (A12) & 0.5720 & 0.2251 & 83 \\
\hline & & Use of green materials (A13) & 0.1094 & 0.0430 & 86 \\
\hline & & Green material market price (A14) & 0.1094 & 0.0430 & 71 \\
\hline \multirow{3}{*}{ Technical indexes (A2) } & \multirow{3}{*}{0.3935} & $\begin{array}{l}\text { Operations management technology } \\
\text { (A21) }\end{array}$ & 0.1196 & 0.0471 & 79 \\
\hline & & Green technology usage (A22) & 0.3091 & 0.1216 & 82 \\
\hline & & New technology applicability (A23) & 0.5713 & 0.2248 & 93 \\
\hline \multirow{3}{*}{ Personnel indexes (A3) } & \multirow{3}{*}{0.1376} & Personnel employed (A31) & 0.1096 & 0.0151 & 96 \\
\hline & & Technical staff training (A32) & 0.5813 & 0.0800 & 90 \\
\hline & & $\begin{array}{c}\text { Management personnel participation } \\
\text { (A33) }\end{array}$ & 0.3091 & 0.0425 & 86 \\
\hline \multirow{4}{*}{$\begin{array}{l}\text { Environmental indexes } \\
\text { (A4) }\end{array}$} & \multirow{4}{*}{0.0754} & Gas pollution treatment (A41) & 0.1667 & 0.0126 & 90 \\
\hline & & Noise pollution control (A42) & 0.4999 & 0.0377 & 94 \\
\hline & & Solid pollution treatment (A43) & 0.1667 & 0.0126 & 81 \\
\hline & & Sewage treatment (A44) & 0.1667 & 0.0126 & 79 \\
\hline \multicolumn{5}{|c|}{ Comprehensive scores } & 86.6 \\
\hline
\end{tabular}

\subsection{Grade Determination and Result Analysis}

Based of the cost survey of the whole project, we got the score of the green building life cycle cost evaluation index. If the score is less than 50, indicating that the cost control level is poor. If the score between 50 to 60 , indicating that the cost management at a moderate level. If the score between 60 to 80 , indicating that the cost management at a good level. If the score between 80 to 100, indicating that the cost management at an excellent level.

Thus, the life cycle cost of this project is at an excellent level. This shows that the green building life cycle cost is reasonable. But from each index score, we can see that there are still some deficiency. For example, the high cost of green materials, the lack of operational management technology and the higher cost of sewage treatment. This requires the project team members from all aspects to control and improve, so that the indexes are moving in the positive direction.

\section{Conclusion}

Green building construction is a work which has been paid much attention to the country in recent years. On the basis of expounding the connotation and characteristics of green building, this paper uses the life cycle theory to analyze the influencing factors of green building cost. Then, this paper take a green residential district as an example to do the cost evaluation and results analysis, so as to provide idea for the life cycle cost management of green building.

\section{References}

[1]. Zhou Tiantian. Study on the Method of Suitability Screening for Building Energy [D]. Chongqing University. 2012.

[2]. Pan Zhiren. Analysis of green construction management concept to achieve the construction management innovation [J]. Management Manager, 2014 (21).

[3]. Fan Lijun. Study on Green Construction of Participants in Engineering Construction [J]. Journal of Electric Power, 2012.

[4]. Han Peng. Study on construction cost control of Green building [D]. Beijing Jiaotong University, 2014.

[5]. Tang Wei. Preliminary opinion on construction management innovation and green construction management [J]. Building Materials Decoration, 2016. 